\title{
TAXONOMICAL AND CHOROLOGICAL NOTES 2 (20-27)
}

\author{
Viktor PAPP ${ }^{1}$, Gergely KIrÁlY ${ }^{2}$, János Koscsó ${ }^{3}$, \\ Ákos MalatinszKY ${ }^{4}$, Timea NAgY ${ }^{5}$, Attila TAKÁcs ${ }^{6}$ and Bálint DimA ${ }^{7,8}$ \\ ${ }^{1}$ Department of Botany and Soroksár Botanical Garden, Corvinus University of Budapest, \\ H-1518 Budapest,.Pf. 53, Hungary; viktor.papp@uni-corvinus.hu \\ ${ }^{2}$ Institute of Silviculture and Forest Protection, University of West Hungary, \\ H-9400 Sopron, AdyE.u. 5, Hungary; kiraly.gergely@nyme.hu \\ ${ }^{3}$ H-3529 Miskolc, Sályi I.u.16, Hungary; jankos81@gmail.com \\ ${ }^{4}$ Institute of Nature Conservation and Landscape Management, Szent István University, \\ H-2103 Gödöllö, Páter K. u. 1, Hungary; malatinszky.akos@mkk.szie.hu \\ ${ }^{5}$ Department of Plant Sciences and Biotechnology, University of Pannonia, \\ H-8360 Keszthely, Festetics u. 7, Hungary; tima.nagy@gmail.com \\ ${ }^{6}$ Department of Botany, University of Debrecen, \\ H-4032 Debrecen, Egyetem tér 1, Hungary; limodorum.abortivum@gmail.com \\ ${ }^{7}$ Plant Biology, Department of Biosciences, University of Helsinki, \\ P. O. Box65, 00014 Helsinki, Finland; dima.balint@helsinki.fi \\ ${ }^{8}$ Department of Plant Anatomy, Institute of Biology, Eötvös Loránd University, \\ H-1117 Budapest, Pázmány Péter sétány 1/c, Hungary; cortinarius1@gmail.com
}

Papp, V., Király, G., Koscsó, J., Malatinszky, Á., Nagy, T., Takács, A. \& Dima, B. (2016): Taxonomical and chorological notes 2 (20-27). - Studia bot. hung. 47(1): 179-191.

\begin{abstract}
The second part of the recently launched series includes miscellaneous new records from fungi to vascular plants. New chorological records of five taxa of fungi are provided here: two new for Hungary (Entoloma tjallingiorum and Mycoacia nothofagi), one (Hohenbuehelia mastrucata) new for the Vértes and Börzsöny Mts, additional records and confirmations for two taxa (Entoloma lampropus and Hohenbuehelia atrocoerulea) are also provided. New chorological records of three vascular plants are provided: one taxon (Draba muralis) new for the Tiszántúl region, two (Rubus armeniacus and Najas marina) new for the North Hungarian Mts.
\end{abstract}

Key words: Brassicaceae, Entolomataceae, Hungary, Hydrocharitaceae, Meruliaceae, Pleurotaceae, Rosaceae

\section{INTRODUCTION}

This paper is the second part of the series launched in Studia botanica bungarica focusing on the new chorological records, nomenclature, and taxonomy of plant species from algae to vascular plants and fungi (BARINA et al. 2015). 


\title{
MATERIAL AND METHODS
}

For the fungal specimens the Phire Plant Direct PCR Kit (Thermo Scientific, USA) was used for the DNA extraction and PCR following the recommendations of the manufacturer.

The ITS region of the nrDNA was amplified with the primer pairs ITS1F/ ITS4 (White et al. 1990). The amplicons were sequenced at LGC Genomics (Berlin, Germany) with the same primers used in PCR reactions. The chromatograms were checked, assembled and edited with the Pregap4 and Gap4 programs of the Staden package (STADEN et al. 2000) as well as with the CodonCode Aligner package (CodonCode Corp., Centerville, Massachusetts, USA).

For the dataset of Entoloma and Hohenbuehelia multiple sequence alignments were done with PRANK (LÖYTYNOJA and GoldmAN 2005) as implemented in its graphical interface (PRANKSTER) under default settings. Mycoacia sequences were aligned by MAFFT (online version 7) using the E-INS-i algorithm (КАтон and Тон 2008). After manual adjustments in SeaView (GouY et al. 2010) the phylogenetically informative indels were coded in the three alignments, following the simple indel coding algorithm (Simmons et al. 2001) with the program FastGap 1.2 (BoRCHSENIUS 2009).

Bayesian inference (BI) analyses were performed with MrBayes 3.1.2 (RoNQUIST et al. 2012). The nucleotide and indel characters were split into two partitions to which the GTR + G and two-parameter Markov model, respectively, were applied. Four Markov chains were run for 10,000,000 generations, sampling every 1000th generation and with a burn-in of every 3,000 sampled trees. The post burn-in trees were used to compute a $50 \%$ majority rule consensus phylogram and posterior probabilities (PP) were calculated.

Maximum Likelihood (ML) analysis was carried out using RAxML (STAMATAKIs 2014) in raxmlGUI (SILVESTRO and MichalAK 2012). Rapid bootstrap analysis and 1,000 replicates under the GTRGAMMA substitution model were used for the partitioned alignment (ITS + indels). The newly generated sequences were deposited in GenBank (Figs 1-3).

\section{NEW RECORDS WITH ANNOTATIONS}

\author{
Fungi
}

(20) Entoloma tjallingiorum Noordel. (Entolomataceae)

Hungary, Vértes Mts: near Csákberény, Juhdöglö-völgy Forest Reserve, on Quercus sp.; leg. V. Papp, 07.10.2010, BP 106905 (PV538), GenBank: KX349905

For comments see Entoloma lampropus. 
(21) Entoloma lampropus (Fr.) Hesler

Hungary, Zemplén Mts: Pálháza-Kökapu, in the valley of the Kemence-patak, in Alnetum; leg. B. Dima, 24.09.2006, BP 106906 (DB2529), GenBank: KX349904

Entoloma (Fr.) P. Kumm. s. lato is a cosmopolitan species-rich genus of Agaricales with highly variable sporocarp morphology (Noordeloos and Morozova 2010). The life strategies are equally varied in the genus; most of the species are terrestrial or wood-inhabiting saprotrophs, but some are parasitic or mycorrhizal symbionts (LARGENT 1994, Noordeloos 1992, 2004, Noordeloos and GATES 2012). Several authors considered that the genus Entoloma is polyphyletic, and certain clades and morphological groups have been treated as separate genera (e.g. AIME et al. 2010, BARONI et al. 2011, HENKEL et al. 2010, 2014, LARgent et al. 2011a, b, 2013a, b, Ovrebo and BARONi 2007). However, other authors stated that the genus is one species-rich entity with extensive infrageneric classification (e.g. Co-DAvid et al. 2009, Morgado et al. 2013, Noordeloos 2004, Noordeloos and Gates 2012), hence the different lineages (e.g. Leptonia group) are discussed below genus level (subgenera, sections, etc.) (e.g. Morozova et al. 2014, Noordeloos 1982). Since the polyphyly of the genus Entoloma has not yet been unambiguously proved even with the help of multi-gene phylogenetic analyses, we still treat the species of the Leptonia group within the genus.

The type species of the Entoloma subgen. Leptonia (Fr.) Noordel. emend. O. V. Morozova, Noordel. et Vila (三Leptonia (Fr.) P. Kumm.) is Agaricus euchrous Pers. (三Entoloma euchroum (Pers.) Donk) (Noordeloos 1981), which is characterised by blue-violaceous colour of the basidiocarp, sweet smell, and lignicolous habitat (NoORdELOos 1992). Based on a recent phylogenetic study of the subgenus Leptonia in boreal-temperate Eurasia (Morozova et al. 2014), the section Leptonia forms a well-supported monophyletic clade including only those species, which have weakly angled, almost nodulose spores: Entoloma chytrophilum Wölfel, Noordel. et Dähncke, E. euchroum, E. lampropus (Fr.) Hesler, E. placidum (Fr.) Noordel., E. sublaevisporum Vila, Noordel. et O. V. Morozova, E. tjallingiorum Noordel. s. lato. Three of these species have been recorded from Hungary in the literature, however, only based on morphological identification: E. lampropus, E. euchroum, and E. placidum (e.g. LukÁcs 2007, SÁnTHa 2003).

The Hungarian specimen (BP 106905) was found as new for Hungary in the Juhdöglö-völgy Forest Reserve (Vértes Mts) and identified as E. tjallingiorum based on morphology. In our phylogenetic analyses the ITS sequence of this specimen nested in the subclade of E. tjallingiorum var. tjallingiorum according to Morozova et al. (2014), and it clustered together with the sequence obtained from the type material (KC898412) with strong support $(\mathrm{PP}=1.00, \mathrm{BS}=100 \%)$ 
(Fig. 1). A new occurrence of another member of the sect. Leptonia, E. lampropus for Hungary, was verified by ITS data too. Our collection from the Zemplén Mts clustered together with the neotype sequence of the species (KC898377) and also gained maximum support in both BI and ML analyses (Fig. 1).

The Entoloma tjallingiorum species complex treated in Morozova et al. (2014) needs further taxonomical revision based on our phylogenetic analyses, because the recently described variety, E. tjallingiorum var. laricinum from Kamchatka, Russia

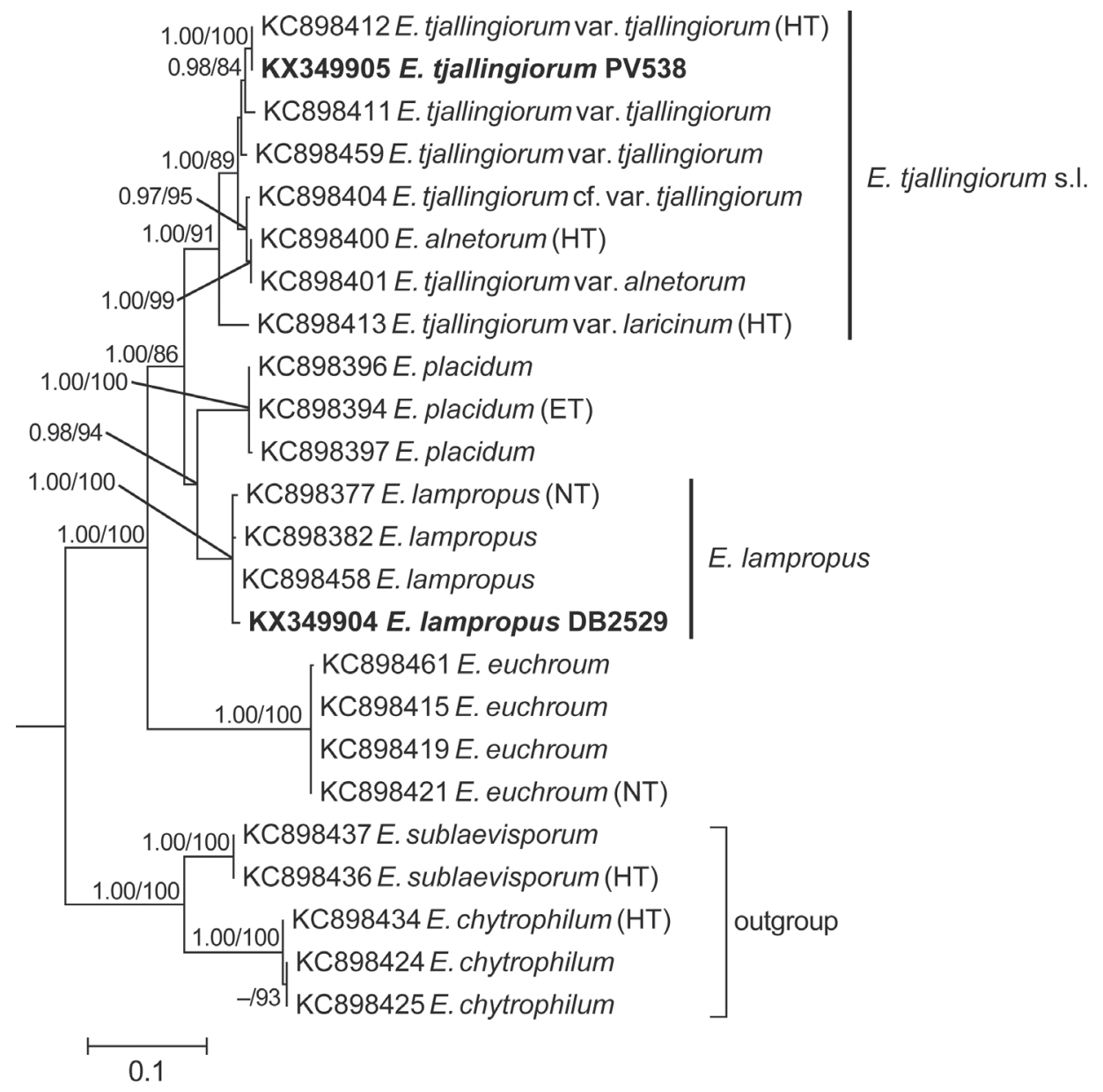

Fig. 1. 50\% majority rule consensus phylogram derived from Bayesian inference analysis of nrDNA ITS sequences of Entoloma species. Entoloma sublaevisporum and E. chytrophilum served as outgroup. Numbers at branches represent nodal support (BI posterior probability (PP) and ML bootstrap percentage). Voucher numbers are indicated only at the two newly generated sequences which are marked in boldface. Abbreviations: $\mathrm{HT}=$ holotype, $\mathrm{ET}=$ epitype, $\mathrm{NT}=$ neotype. Scale bar indicates 0.1 expected changes per site per branch. 
has a significant genetic distance (only $96 \%$ similarity in the ITS region) compared to the two other varieties (var. tjallingiorum and var. alnetorum).

V. Papp and B. Dima

\section{(22) Hobenbuehelia mastrucata (Fr.) Singer (Pleurotaceae)}

Hungary, Vértes Mts: near Csákberény, Juhdöglö-völgy Forest Reserve, on Fagus sylvatica log; leg. V. Papp, 01.08.2012, BP 106919 (PV712), GenBank: KX349907. - Hungary, Vértes Mts: near Csákberény, Juhdöglö-völgy Forest Reserve, on Fagus sylvatica log; leg. V. Papp, 25.10.2013, BP 106920 (PV1019). - Hungary, Börzsöny Mts: near Hont, on decayed hardwood; leg. V. Papp, 08.10.2014, BP 106927.

For comments see Hohenbuehelia atrocoerulea.

\section{(23) Hobenbuebelia atrocoerulea (Fr.) Singer}

Hungary, Vértes Mts: near Csákberény, Juhdöglö-völgy Forest Reserve, on Quercus petraea log; leg. V. Papp, 24.10.2012, BP 106921 (PV774), GenBank: KX349906. - Hungary, Vértes Mts: near Csákberény, Juhdöglö-völgy Forest Reserve, on Fagus sylvatica log; leg. V. Papp, 24.10.2012, BP 106922 (PV776).

Hohenbuehelia Schulzer (anamorphic synonym: Nematoctonus Drechsler) is a cosmopolitan saprotrophic and nematode-destroying genus in the family Pleurotaceae Kühner belonging to the suborder Pleurotineae Aime, Dentinger et Gaya (Dentiger et al. 2016) in Agaricales Underw. The genus is morphologically characterised by crepidotoid to pleurotoid, rarely omphalinoid basidiocarp and the gelatinous zone beneath the pileipellis, and metuloid pseudocystidia (KozIAK et al. 2007, THORN and BARRON 1986).

Hohenbuehelia mastrucata was described by FrIES (1818) as Agaricus mastrucatus and it is characterised by crepidotoid basidiocarp, greyish to sordid white pileus with conical scales, and relatively thick (up to $1.5 \mathrm{~mm}$ ) gelatinous layer (ELBORNE 2012). KRIEGLSTEINER (2000) earlier stated that it is a variety of $H$. atrocoerulea, however, our phylogenetic analysis that includes the ITS sequences of both epitypes selected by CoNsiglio (2016) did not support this morphological concept. The ITS sequence of the Hungarian specimen (BP 106919) found in the Juhdöglö-völgy Forest Reserve (Vértes Mts) nested in the subclade of $H$. mastrucata and clustered together with the ITS sequences obtained from the epitype material (KU355336) and two North American specimens (KP026227, EF409736) with strong support (PP = 1.00, BS $=100 \%$ ) (Fig. 2). In addition, a new Hungarian occurrence of the more frequent $H$. atrocoerulea (e.g. Dima et al. 2010, LukÁcs 2010) from the Vértes Mts was also verified by ITS data, which clustered together with the epitype (KU355304) and the two other sequences originated from China: GQ142024 (as "H. reniformis") and GQ219732 (as undetermined Hohenbuehelia species) (Fig. 2). 


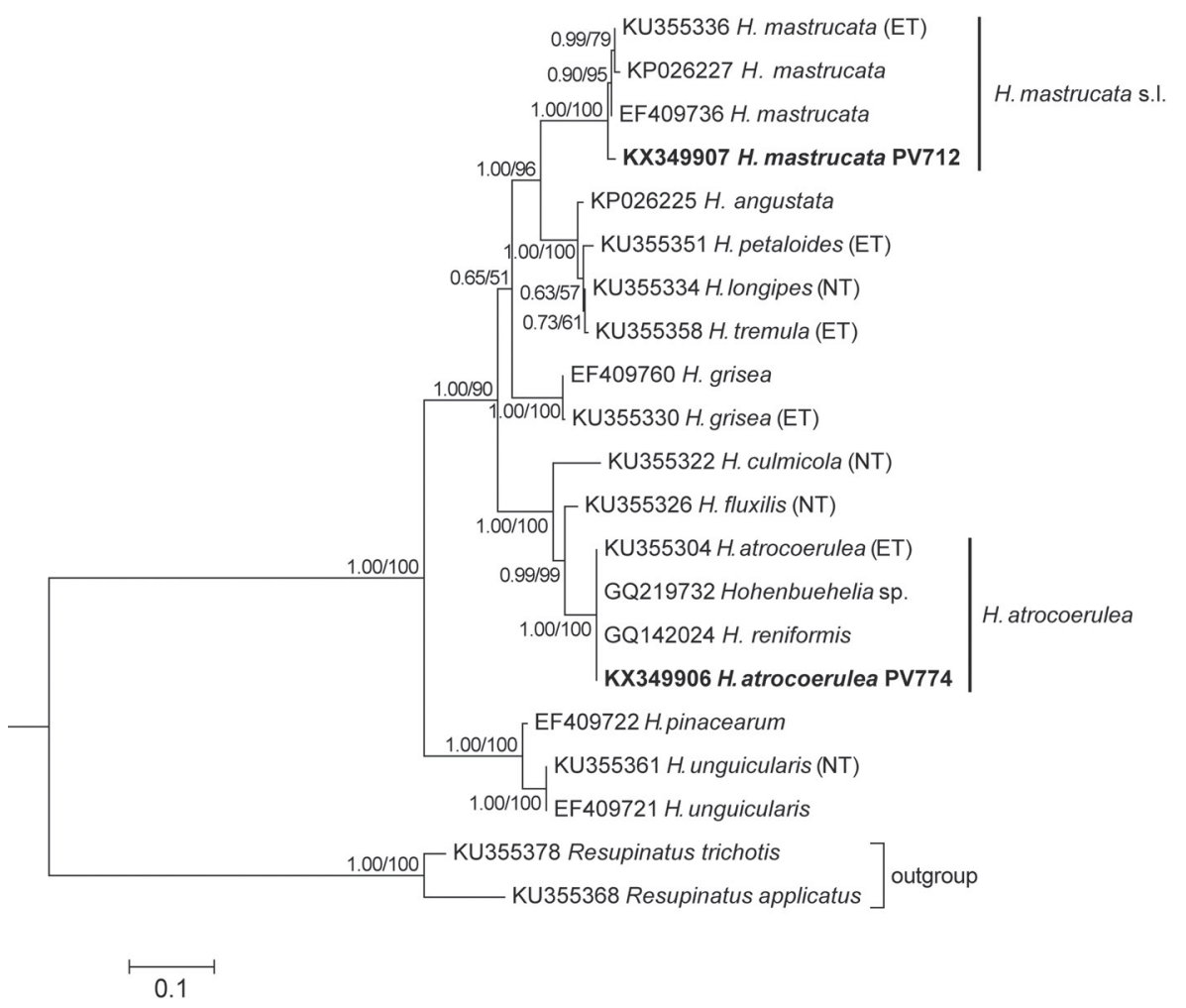

Fig. 2. 50\% majority rule consensus phylogram derived from Bayesian inference analysis of nrDNA ITS sequences of Hohenbuehelia species. Resupinatus trichotis and $R$. applicatus served as outgroup. Numbers at branches represent nodal support (BI posterior probability (PP) and ML bootstrap percentage). Voucher numbers are indicated only at the two newly generated sequences which are marked in boldface. Abbreviations: ET = epitype, $\mathrm{NT}=$ neotype. Scale bar indicates 0.1 expected changes per site per branch.

In Hungary Hohenbuehelia mastrucata is listed on the unofficial red list of macrofungi (RImóczi et al. 1999) as a critically endangered species. Reference to Hungarian occurrence has been found in the collection of László Hollós (as Pleurotus mastrucatus) from the surroundings of Szekszárd (BABOs 1984). Later BABOS (1989), in her comprehensive work based on the fungal collections of the Hungarian Natural History Museum (BP), mentioned only a single known locality of this species from the Szentendre Island (Central Hungary), on Populus log. NAGY and Gorliczai (2007) published a new record (as H. atrocoerulea var. mastrucata) from Kecskemét-Tőserdő (Southern Great Plain). Herein, new Hungarian records of this taxon are presented from the Juhdöglö-völgy Forest Reserve (Vértes Mts, Central Transdanubia) and the Börzsöny Mts (Northern Hungary).

V. Papp and B. Dima 


\section{(24) Mycoacia nothofagi (G. Cunn.) Ryvarden (Meruliaceae)}

Hungary, Vértes Mts: near Csákberény, Juhdöglö-völgy Forest Reserve, on Fagus sylvatica log; leg. V. Papp, 22.07.2011, BP 106923 (PV387). - Hungary, Vértes Mts: near Csákberény, Juhdöglö-völgy Forest Reserve, on Fagus sylvatica log; leg. V. Papp, 22.07.2011, BP 106924 (PV549). - Hungary, Vértes Mts: near Csákberény, Juhdöglö-völgy Forest Reserve, on Fagus sylvatica log, $47.380483^{\circ} \mathrm{N}, 18.337427^{\circ}$ E; leg. V. Papp, 03.08.2011, BP 106925 (PV551), GenBank: KX349908. - Hungary, Vértes Mts: near Csákberény, Juhdöglö-völgy Forest Reserve, on Fagus sylvatica log, 47.380283 N, $18.337561^{\circ}$ E; leg. V. Papp, 20.10.2012, BP 106926 (PV1031)

The resupinate hidnoid fungus, Mycoacia nothofagi (三 Phlebia nothofagi (G. Cunn.) Nakasone) is distinguished by the monomitic hyphal system and the rather thick-walled, densely encrusted hymenial cystidia (NAKASONE 1997). The type of this species (as "Odontia nothofagi G. Cunn.") was described from New Zealand, where it was grown on Nothofagus menziesii (Hook. f.) Oerst. (CunNingham

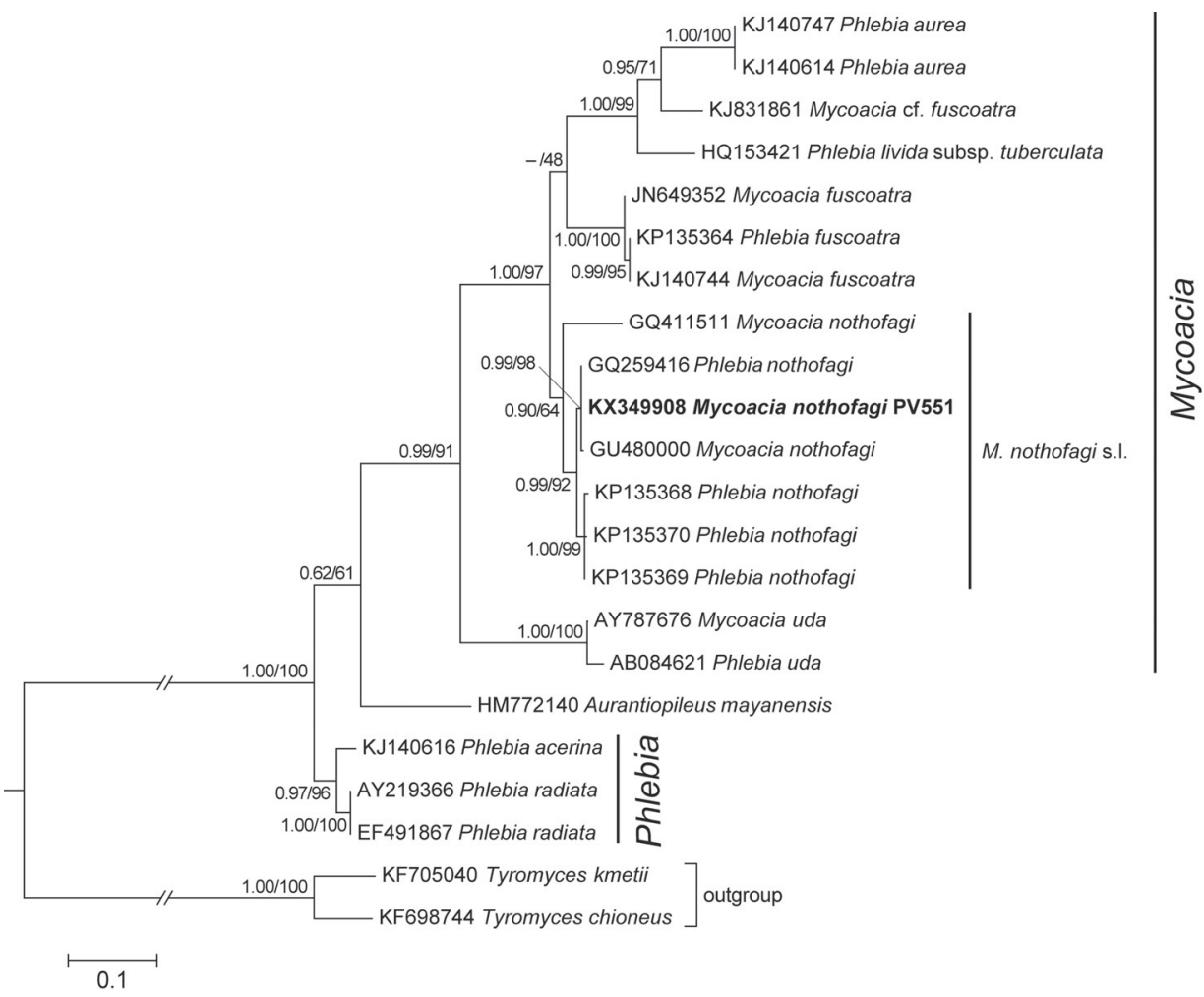

Fig. 3. 50\% majority rule consensus phylogram derived from Bayesian inference analysis of nrDNA ITS sequences of Mycoacia species. Tyromyces kmetii and T. chioneus served as outgroup. Numbers at branches represent nodal support (BI posterior probability (PP) and ML bootstrap percentage). Voucher numbers are indicated only at the two newly generated sequences which are marked in boldface. Scale bar indicates 0.1 expected changes per site per branch. 
1959). In Europe it was known as an indicator species of natural beech forests (Christensen et al. 2004), nevertheless, Bernicchia and Gorjón (2010) mentioned from different substrata (Populus nigra, Ulmus glabra, Quercus ilex, and Abies alba). In Europe it is known from Bosnia and Herzegovina, Bulgaria, Czech Republic, Germany, Great Britain, France, Italy, Portugal, Romania, Slovakia, Spain, and Switzerland (BERnicChia and GorJón 2010, NAKASONE 1997). In this study, Mycoacia nothofagi is reported as new to Hungary.

The ITS sequence obtained from the Hungarian specimen (BP 106925) identified as Mycoacia nothofagi based on morphology nested in the clade of $M$. nothofagi s. lato and it belonged to the subclade formed by exclusively European sequences published by MORENO et al. (2011) from Spain (GQ259416) and France (GU480000). The sequences of $M$. nothofagi originating from the USA (KP135368, KP135369, KP135370) and published by FloudAs and HibBetT (2015) formed a sister clade of the European sequences with strong support. Furthermore, the ITS sequence (GQ411511) originating from the type locality area (New Zealand) showed significant difference towards the North American and European sequences (only $91 \%$ similarity in the ITS region), which can well be enough for species level separation of these subclades (Fig. 3).

If the sequence from New Zealand (GQ411511) published by FuKAMI et al. (2010) was identical with the type material of $M$. nothofagi (PDD7281), the European and North American " $M$. nothofagi" should probably be described as new species. However, to clarify the species limits in the complex, molecular examination of the type specimen of $M$. nothofagi and other samples, in addition to a comprehensive morphological survey, would be required.

V. Papp and B. Dima

\section{Vascular plants}

\section{(25) Draba muralis L. (Brassicaceae)}

Hungary, South Tisza Valley: Szentes, on the left side embankment of the river Tisza, in uncharacteristic secondary grasslands, $\sim 46.68465^{\circ} \mathrm{N}, \sim 20.20916^{\circ} \mathrm{E}, 80 \mathrm{~m},(9387.1)$; leg. A. Takács and T. Nagy, 12.04.2015, DE-Soo-38837.

Draba muralis L. is distributed from the Iberian Peninsula and North Africa (Morocco, Algeria) to the Caucasus Mountains and to the south of Sweden and Finland (JALAS et al. 1996) including introductions, e.g. in UK, France, Germany, Austria (RATCLIFFE 1960, JALAS et al. 1996), and maybe in the northern part of the area (WALTERS and AKEROYD 1993). In the south of its range D. muralis is connected to higher altitudes (RATCLIFFE 1960). This annual species generally 
occurs on open, stony soils or sands (e.g. OBERDORFER 1949, RATCLIFFE 1960, WALTERS and AKEROYd 1993).

The presence of this taxon in Hungary is well known (JÁvorKA 1924, SIMON 1992, BARINA 2009), but the known occurrences are confined to colline regions of Transdanubia and the western part of the North Hungarian Mountains (Börzsöny, Naszály) (BARINA 2009, BARTHA et al. 2015). The first record of $D$. muralis in the Tiszántúl region was discovered in spring, 2015. A few hundreds of individuals grew on the outside (floodless) slope of Tisza's embankment, exposed to NE, in uncharacteristic, secondary mesophile grasslands. Supposedly, this remote occurrence is a result of introduction, since (i) there are no other known localities of $D$. muralis in the Tiszántúl and the Duna-Tisza Interfluve, (ii) the floodplain of Tisza with non-calcareous sediments represents unfavourable habitats for this species, (iii) in addition, it appeared on a construction where tourist traffic is general.

A. Takács and T. Nagy

(26) Rubus armeniacus Focke (Rosaceae)

Hungary, North Hungarian Mts (Északi-középhegység), Miskolci-Bükkalja micro-region, Miskolc, Köporos Str., spreading spontaneously in hedges, $48.10595^{\circ} \mathrm{N}, 20.75559^{\circ} \mathrm{E}, 145 \mathrm{~m}$; leg. J. Koscsó, 03.05.2014, det.: G. Király (7890.4); - Rákóczi Str., spontaneous scrub at a garden retaining wall, $48.10035^{\circ} \mathrm{N}, 20.78244^{\circ} \mathrm{E}, 135 \mathrm{~m}$; leg. J. Koscsó, 25.08 .2015 , det.: G. Király (7890.4). - Miskolc, Tímár Str., shrubbery at a garden fence, $48.07063^{\circ} \mathrm{N}, 20.75798^{\circ} \mathrm{E}, 129 \mathrm{~m}$; leg. G. Király \& A. Schmotzer, 18.04.2016 (7990.2).

Rubus armeniacus (Rubus ser. Discolores (P. J. Müller) Focke) is an invasive alien bramble of Caucasian origin that became widespread in Central and Western Europe in the last century (KuRTto et al. 2010, Weber 1995,). The species was first recognised with scattered occurrences mainly W of the Danube River in Hungary by KIRÁLY et al. (2014), whereas it has not been yet recorded in the northeastern part of the country. Here we report on the first occurrences in the North Hungarian Mts (and, at the same time, in the Carpathians) based on some introduced stands found in the vicinity of Miskolc. The species is probably a garden escape in this city that grows both in urban and suburban areas and shows unambiguously an advancing tendency; this behaviour is similar to those observed e.g. in the case of cities of Sopron and Budapest in Hungary. The further expansion of the species is expected in semi-ruderal habitats of the Turkey oak and forest steppe belts in the North Hungarian Mts (e.g. along railways, in black locust woods and abandoned pastures), however, its spreading seems to be rather unlikely in closed natural forest communities of the region.

G. Király and J. Koscsó 


\section{(27) Najas marina L. (Hydrocharitaceae)}

Hungary, Hernád Valley: Hernádszurdok, in an abandoned meander (oxbow) between Felső-rét and Malom-szer areas; leg. Á. Malatinszky, 20.07.2013, s.n. (photodocumented) (7593.1).

This species is widespread across Europe, Africa, Asia, the Americas, Australia, and several oceanic islands, in various aquatic habitats from freshwaters till brackish aquatic habitats, including alkaline lakes (STUCKEY 1985).

Although this taxon is known from several locations on the Great Hungarian Plain, the Lake Balaton, and Western Transdanubia, no records were found so far in the Northern Hungarian floristical region (Matricum). Its closest localities are found in the interfluve of the Bodrog and Tisza rivers (BARTHA et al. 2015). Therefore, this record largely extends the species' known area in Hungary.

\section{Á. Malatinszky}

Acknowledgements - Work of Attila Takács was supported by NTP-EFÖ-P-15 project, and work of Ákos Malatinszky by Research Centre of Excellence 11476-3/2016/FEKUT.

Összefoglaló: Jelen közleményünk a tavaly megkezdett, regionális jelentőségű előfordulásokat és nevezéktani megjegyzéseket tartalmazó sorozat (BARINA et al. 2015) második része. Ebben a részben két, hazánkra új gombafaj (Entoloma tjallingiorum és Mycoacia nothofagi) adatát; egy, a Vértes és a Börzsöny területére új gombafajét (Hohenbuehelia mastrucata); valamint két további gombafaj (Entoloma lampropus és Hohenbuehelia atrocoerulea) megerősítését és új adatait közöljük. A Tiszántúl területére újként közöljük a Draba muralis előfordulását és az Északi-középhegység területére a Rubus armeniacus és Najas marina előfordulását. Utóbbiak közül a Draba muralis tiszántúli megjelenése behurcolás, míg a Rubus armeniacus miskolci megjelenése kivadulás eredménye lehet.

\section{REFERENCES}

Aime, M. C., Largent, D. L., Henkel, T. W. and Baroni, T. J. (2010): The Entolomataceae of the Pakaraima Mountains of Guyana IV: new species of Calliderma, Paraeccilia and Trichopilus. - Mycologia 102(3): 633-649. http://dx.doi.org/10.3852/09-162

BARINA, Z. (2009): Draba L. - In: KiráLY, G. (ed.): Új magyar füvészkönyv. Magyarország hajtásos növényei. Határozókulcsok. (New Hungarian herbal. The vascular plants of Hungary. Identification key). Aggteleki Nemzeti Park Igazgatóság, Jósvafö, p. 184.

Barina, Z., Benedek, L., Boros, L., Dima, B., Folcz, Á., Király, G., Koszka, A., Malatinszzy, Á., PAPP, D., PIf Kó, D., and PAPP, V. (2015): Taxonomical and chorological notes 1 (1-19). Studia bot. hung. 46(2): 205-222. http://dx.doi.org/10.17110/studbot.2015.46.2.205

Baroni, T. J., Hofstetter, V., Largent, D. L. and Vilgalys, R. (2011): Entocybe is proposed as a new genus in the Entolomataceae (Agaricomycetes, Basidiomycota) based on morphological and molecular evidence. - North American Fungi 6(12): 1-19. http://dx.doi.org/10.2509/naf2011.006.012

Bartha, D., Király, G., Schmidt, D., Tiborcz, V., Barina, Z., Csiky, J., Jakab, G., Lesku, B., SChmotzer, A., Vidéki, R., Vojt kó, A. and Zólyomi, Sz. (2015): Magyarország edényes 
növényfajainak elterjedési atlasza. [Distribution of vascular plants of Hungary]. - Nyugatmagyarországi Egyetem Kiadó, Sopron, 108 pp.

Bernicchia, A. and Gorjón, S. P. (2010): Corticiaceae s. l. (Fungi Europaei 12). - Candusso, Alassio, $1008 \mathrm{pp}$.

BorchseniUs, F. (2009): FastGap 1.2. - http://www.aubot.dk/FastGap_home.htm, Department of Biosciences, Aarhus University, Denmark (accessed 31.05.2016)

Christensen, M., Heilmann-Clauswn, J., Walleyn, R. and Adamčik, S. (2004): Woodinhabiting fungi as indicators of nature value in European beech forests. - In: MARCHETTI, M. (ed.): Monitoring and indicators of forest biodiversity in Europe from ideas to operationality. EFI Proceedings 51: 229-237.

Co-David, D., Langeveld, D. and Noordeloos, M. E. (2009): Molecular phylogeny and spore evolution of Entolomataceae. - Persoonia 23: 147-176.

http://dx.doi.org/10.3767/003158509x480944

Consiglio, G. (2016): Nomenclatural novelties. - Index Fungorum 292: 1.

Cunningham, G. H. (1959): Hydnaceae of New Zealand. II. The genus Odontia. - Trans. Proc. Roy. Soci. New Zealand 86(1): 65-103.

Dentiger, B. T. M., Gaya, E., O’Brien, H., Suz, L. M., Lachlan, R., Díaz-Valderrama, Koch, R. A. and Aime, M. C. (2016): Tales from the crypt: genome mining from fungarium specimens improves resolution of the mushroom tree of life. - Biol. J. Linn. Soc. 117: 11-32. http://dx.doi.org/10.1111/bij.12553

Floudas, D. and Hibbett, D. S. (2015): Revisiting the taxonomy of Phanerochaete (Polyporales, Basidiomycota) using a four gene dataset and extensive ITS sampling. - Fungal Biology 119: 679-719. http://dx.doi.org/10.1016/j.funbio.2015.04.003

Fries, E. M. (1818): Observationes mycologicae. Vol. 2. - Gerh. Bonnier, Copenhagen, 372 pp.

Fukami, T., Dickie, I. A., Paula Wilkie, J., Paulus, B. C., Park, D., Roberts, A., Buchanan, P. K. and Allen, R. B. (2010): Assembly history dictates ecosystem functioning: evidence from wood decomposer communities. - Ecol. Letters 13: 675-684. http://dx.doi.org/10.1111/j.1461-0248.2010.01465.x

Gouy, M., Guindon, S. and Gascuel, O. (2010): SeaView version 4: a multiplatform graphical user interface for sequence alignment and phylogenetic tree building. - Mol. Biol. Evol. 27(2): 221-224. http://dx.doi.org/10.1093/molbev/msp259

Henkel, T. W., Aime, M. C., Largent, D. L. and Baroni, T. J. (2010): The Entolomataceae of the Pakaraima Mountains of Guyana 5: new species of Alboleptonia. - Mycotaxon 114: 115-126. http://dx.doi.org/10.5248/114.115

Henkel, T. W., Aime, M. C., Largent D. L. and Baroni, T. J. (2014): The Entolomataceae of the Pakaraima Mountains of Guyana 6: ten new species and a new combination in Nolanea. - Mycotaxon 129(1): 119-148. http://dx.doi.org/10.5248/129.119

Jalas, J., Suominen, J. and Lampinen, R. (eds) (1996): Atlas Florae Europaeae. Distribution of Vascular Plants in Europe. 11. Cruciferae (Ricotia to Raphanus). - The Committee for Mapping the Flora of Europe and Societas Biologica Fennica Vanamo, Helsinki, p. 106.

JÁvorka, S. (1924): Magyar flóra (Flora hungarica). - Studium, Budapest, pp. 429-431.

КАтон K. and Тон, H. (2008) Recent developments in the MAFFT multiple sequence alignment program. - Briefings in Bioinformatics 9: 286-298. http://dx.doi.org/10.1093/bib/bbn013

KIRÁLY, G., TrÁvNIČEK, B. and ŽILA, V. (2014): Észrevétlen özönfaj a magyar flórában, az örmény szeder (Rubus armeniacus Focke). - Kitaibelia 19(2): 220-228.

Koziak, A. T. E., Cheng, K. C. and Thorn, R. G. (2007): Phylogenetic analyses of Nematoctonus and Hohenbuehelia (Pleurotaceae). - Can. J. Bot. 85: 762-773.

http://dx.doi.org/10.1139/b07-083 
Kurtto, A., Weber, H. E., Lampinen, R. and Sennikov, A. N. (eds) (2010): Atlas Florae Europaeae. Distribution of vascular plants in Europe. 15. Rosaceae (Rubus). - The Committee for Mapping the Flora of Europea and Societas Biologica Fennica Vanamo, Helsinki, 362 pp.

LARgent, D. L. (1994): Entolomatoid fungi of the western United States and Alaska. - Mad. River Press, Inc., Eureka, CA. 516 pp.

Largent, D. L., Abell-Davis, S. E., Cummings, G. A., Ryan, K. L. and Bergemann, S. E. (2011a): Saxicolous species of Claudopus (Agaricales, Entolomataceae) from Australia. Mycotaxon 116: 253-264. http://dx.doi.org/10.5248/116.253

Largent, D. L., Bergemann, S. E., Cummings, G. A., Ryan, K. L., Abell-Davis, S. E. and Moore, S. (2011b): Pouzarella (Agaricales, Entolomataceae) species from New South Wales (Barrington Tops National Park) and northeastern Queensland, Australia. - Mycotaxon 117: 435-483.

Largent, D. L., Bergemann, S. E., Abell-Davis, S. E., Kluting, K. L. and Cummings, G. A. (2013a): Three new Inocephalus species with cuboid basidiospores from New South Wales and Queensland, Australia. - Mycotaxon 123: 301-319. http://dx.doi.org/10.5248/123.301

Largent, D. L., Bergemann, S. E., Abell-Davis, S. E., Kluting, K. L. and Cummings, G. A. (2013b): Five Leptonia species from New South Wales and Queensland, Australia. - Mycotaxon 125: 11-35. http://dx.doi.org/10.5248/125.11

Löytynoja, A. and Goldman, N. (2005): An algorithm for progressive multiple alignment of sequences with insertions. - Proc. Nat. Acad. Sci. USA 102(30): 10557-10562.

LukÁcs, Z. (2007): Újabb adatok Magyarország gombavilágához III. - Mikol. Közlem., Clusiana 46(2): $187-210$.

Moreno, G., Blanco, M.-N., Checa, J., Platas, G. and Peláez, F. (2011): Taxonomic and phylogenetic revision of three rare irpicoid species within the Meruliaceae. - Mycol Progress 10: 481-491. http://dx.doi.org/10.1007/s11557-010-0717-y

Morgado, L. N., Noordeloos, M. E., Lamoureux, Y. and Geml, J. (2013): Multi-gene phylogenetic analyses reveal species limits, phylogeographic patterns, and evolutionary histories of key morphological traits in Entoloma (Agaricales, Basidiomycota). - Persoonia 31: 159-178. http://dx.doi.org/10.3767/003158513x673521

Morozova, O. V., Noordeloos, M. E. and Vila, J. (2014): Entoloma subgenus Leptonia in boreal-temperate Eurasia: towards a phylogenetic species concept. - Persoonia 32: 141-169. http://dx.doi.org/10.3767/003158514x681774

NAGY, L. and GorliczAI, Zs. (2007): Újabb adatok az Alföld gombavilágához. - Mikol. Közlem., Clusiana 46(2): 211-256.

NAKASOne, K. K. (1997): Studies in Phlebia. Six species with teeth. - Sydowia 49(1): 49-79.

Noordeloos, M. E. (1981): Introduction to the taxonomy of the genus Entoloma sensu lato (Agaricales). - Persoonia 11: 121-151.

Noordeloos, M. E. (1982): Entoloma subgenus Leptonia in northwestern Europe. I. Introduction and a revision of its section Leptonia. - Persoonia 11: 451-471.

Noordeloos, M. E. (1992): Entoloma s.l. Fungi Europaei. Vol. 5. - Giovanna Biella, Italy. 429 pp.

Noordeloos, M. E. (2004): Entoloma s. l. Supplemento. Fungi Europaei. Vol. 5a. - Ed. M. Candusso, Alassio, Italia, pp. 761-1378.

Noordeloos, M. E. and Morozova, O. V. (2010): New and noteworthy Entoloma species from the Primorsky Territory, Russian Far East. - Mycotaxon 112: 231-255.

http://dx.doi.org/10.5248/112.231

Noordeloos, M. E. and Gates, G. M. (2012): The Entolomataceae of Tasmania. Fungal Diversity Research Series. Vol. 22 - Springer Dordrecht, Heidelberg, New York, London. 393 pp.

Ovrebo, C. L. and Baroni, T. J. (2007): New taxa of Tricholomataceae and Entolomataceae (Agaricales) from Central America. - Fungal Diversity 27: 157-170. 
RATClifFe, D. (1960): Draba muralis L. - J. Ecol. 48(3): 737-744. http://dx.doi.org/10.2307/2257348

Rimóczi, I., Siller, I., VASAs, G., Albert, L., Vetter, J. and Bratek, Z. (1999): Magyarország nagygombáinak javasolt vörös listája. - Mikol. Közlem., Clusiana 38(1-3): 107-132.

Roneuist, F., Teslenko, M., van der Mark, P., Ayres, D. L., Darling, A., Höhna, S., Larget, B., Liu, L., Suchard, M. A. and Huelsenbeck, J. P. (2012): MrBayes 3.2: efficient Bayesian phylogenetic inference and model choice across a large model space. - Syst. Biol. 61: 539-542. http://dx.doi.org/10.1093/sysbio/sys029

SÁNTHA, T. (2003): Adatok a Kárpát-medence közép-keleti részének Entoloma (Agaricales) kutatásáról. - Mikol. Közlem., Clusiana 42(1-2): 107-122.

Simmons, M. P., Ochoterena, H. and Carr, T. G. (2001): Incorporation, relative homoplasy, and effect of gap characters in sequence-based phylogenetic analysis. - Syst. Biol. 50(3): 454462. http://dx.doi.org/10.1080/106351501300318049

Simon, T. (1992): A magyarországi edényes flóra határozója. Harasztok - virágos növények. [The identification book of the vascular flora of Hungary. Ferns and flowering plants]. - Tankönyvkiadó, Budapest, 434 pp.

Silvestro, D. and Michalak, I. (2012): raxmlGUI: a graphical front-end for RAxML. - Organisms Diversity \& Evolution 12: 335-337. http://dx.doi.org/10.1007/s13127-011-0056-0

Staden, R., BeAl, K. F. and Bonfield, J. K. (2000): The Staden package, 1998. - Meth. Mol. Biol. 132: $115-130$.

STAMATAKIs, A. (2014): RAxML version 8: a tool phylogenetic analysis and post-analysis of large phylogenies. - Bioinformatics 30: 1312-1313.

STUCKeY, R. L. (1985): Distributional history of Najas marina (spiny naiad) in North America. Bartonia 51: 2-16.

Thorn, R. G. and Barron, G. L. (1986): Nematoctonus and the Tribe Resupinateae in Ontario Canada. - Mycotaxon 25: 321-454.

Walters, S. M. and Akeroyd J. R. (1993): Draba L. - In: Tutin, T. G., Burges, N. A., Chater, A. O., Edmondson, J. R., Heywood, V. H., Moore, D. M., Valentine, D. H., Walters, S. M. and WebB, D. A. (eds): Flora Europaea. Vol. 1. Cambridge University Press, pp. 372-377.

Weber, H. E. (1995): Rubus. - In: Weber, H. E. (ed.): Gustav Hegi, Illustrierte Flora von Mitteleuropa, Ed. 3, Vol. 4/2A. Blackwell Wissenschafts-Verlag, Berlin, Oxford etc., pp. 284-595.

White, T. J., Bruns, T., LeE, S. and TAYLOR, J. (1990): Amplification and direct sequencing offungal ribosomal RNA genes for phylogenetics. - In: InNis, M. A., Gelfand, D. H., SNInskY, J, J. and White, T. J. (eds): PCR protocols: a guide to methods and amplifications. Academic, New York, pp 315-322. http://dx.doi.org/10.1016/b978-0-12-372180-8.50042-1 